\title{
ARTICLE AN ETHNOGRAPHY OF JOURNALISTIC PRODUCTION - CASE STUDIES Of THE BRAZILIAN PRESS
}

Copyright (C) 2010 SBPJor / Sociedade Brasileira de Pesquisa em Jornalismo

\author{
ISABEL TRAVANCAS \\ ECO/Universidade Federal do Rio de Janeiro
}

\begin{abstract}
In the present article, my objective is to discuss the production of news based upon ethnographic research that I undertook in Brazilian newsrooms. Journalists have their routines determined by the process of confirming, writing about and divulging information. At this moment in which journalism is undergoing far-reaching transformations, it is more important than ever that we discuss how news is made and according to what criteria.

Here I analyze a major print newspaper, $O$ Globo and the televised news program Jornal Nacional. I point out the similarities and difference between the professional practices of journalists working in these two media forms. Television has a structure and a form of functioning that is quite particular, as well as a more intense rhythm and relationship to imagery than is the case of newspapers. Newspapers, on the other hand, have similar organizations and routines, presenting information that is almost identical from one newspaper to another, even when there is much competition between them.
\end{abstract}

Key words: journalism, routine, ethnography, journalist, news.

\section{INTRODUCTION}

My objective here is to discuss the production of news based upon ethnographic research that I undertook in Brazilian newsrooms. Journalists have their routines determined by the process of confirming, writing about and divulging information. At the present moment, in which journalism is undergoing far-reaching transformations brought about by digitalization and the Internet, it is more important than ever that we discuss what the criteria of this process are and how they are applied.

Brazil has the fifth largest TV network in the world, TV Globo, and this is the only network which broadcasts to every corner of the country. Written media - including newspapers and magazines - do not even come close to TV in terms of market and cultural penetration in our country, especially given the fact that reading is not a habit for a large 
portion of the Brazilian population. The article presented below is the result of ethnographic research undertaken in two different decades in the newsrooms of two newspapers and one TV news program. During my research, I was able to accompany several Brazilian journalists as they went about their daily work, discussing their reports, profession and their relationship to their job.

In the present text, I seek to analyze the routines of professional journalists at one of the major newspapers - $\boldsymbol{O}$ Globo - and at Brazil's most popular TV news program (the Jornal Nacional).. O Globo is the largest newspaper in Rio de Janeiro and one of the most influential and largest in Brazil. It is part of the Rede Globo communications empire, which also maintains TV Globo, the network that has produced the Jornal Nacional since 1969. Jornal Nacional is the 8:00 p.m. newscast of the most important Brazilian TV network and anchors the network's programming, together with Globo's telenovelas (soap operas). It is estimated that the Jornal Nacional currently has an audience of around 30 million viewers during its 45 minute timeslot. This is one of the largest TV audiences in Brazil.

My research allowed me to see the numerous similarities and differences between the professional reporters and news editors in both media forms. Television has a very particular structure and function, with a more intense rhythm than print news. Its subjects are anchored in the views of its journalists and its vast, diversified public and in its intrinsic relationship with images. Newspapers, on the other hand, have an organization and routine that is similar across the board, with subjects that are often identical from one newspaper to another, even though the competition between them may be quite accentuated.

One of the points I wish to emphasize here is that even though ten years separated my research among print journalists from my fieldwork in TV newsrooms, it was quite evident to me that Brazilian journalists continued to have a very intense relationship with their profession in both forms of media and in both periods under study. This relationship with their work creates a very particular worldview and lifestyle which interfere in the selection and preparation of the news.

\section{The Journalist}

The journalist is, above all else, a resident of the city. The urban world which he/she occupies has characteristics and peculiarities that influence the production of news. Sociologist George Simmel (1979) has discerned several characteristic traits of the urban man, among them 
superficiality, anonymity, transitory relationships, sophistication and rationality. Obviously, these characteristics are not exclusive to the career of journalism, but all of them can quite easily be seen in the journalistic lifestyle and, in fact, express themselves as identifying markers of this lifestyle. According to Simmel, the city and (even more intensely) the metropolis determine a new mode of life, new social relations and the creation of occupational categories linked to technological developments in the fields of transportation and communication.

If the city is the place where diversity reigns, where different worlds and "tribes" collide, it is the journalist who most intensely lives this fact in his/her everyday life. One of the primary functions of the reporter - the most paradigmatic character of journalism - is to travel through the different spheres of the metropolis, uncovering and mapping heterogeneous territories that many urban residents are completely unaware of. Simply by confirming facts and relating the news, the reporter becomes something of a citizen of the world.

It is possible to also think of the journalist as something of a mediator. Here I understand "mediation" to be a socio-cultural phenomenon that produces the possibility of exchange and communication through the interaction of individuals (VELHO, 2001, p. 9). In their professional lives, journalists constantly play the role of mediators. Modern urban social life is created through the interaction of differences and these professionals' intermediate relationships with different social categories and groups. Journalists can thus be seen as links between distinct universes of meaning.

Through my study of a group of Brazilian journalists (TRAVANCAS, 1993, p. 102), I can say that if, on the one hand, the profession synthesizes all the characteristics of its individual practitioners, resulting in a totalizing identity prism in which one is a journalist, on the other hand it creates certain tensions between this totalizing role and an individual's kinship and family relationships. I believe that we can talk of a journalist identity that is constructed in spite of this tension, however. In other words, although this identity is neither exclusive nor determinant, it is the synthesis of a series of roles played by an individual and it has several different functions.

The construction of the journalist identity is thus carried out in a context in which several areas of an individual's social life mix and become confused. The journalist's experiences thus present ambiguities and contradictions. One cannot think of identity as something that is made up of conscious and linear projects and trajectories alone. Professional life itself is a source of contact and compromise with this complexity. 
Notions of social prestige and ascension (two concepts which are intimately related) also help to compose the framework in which the journalist identity is constructed. My interviews and ethnographic work make it plain that a career in journalism can, in some cases, be an instrument through which social prestige is obtained and social ascension achieved.

Obviously, this sort of thing varies from person to person. For someone from the upper class who has a prestigious family name and no financial difficulties, the journalist career does not present itself as an opportunity to conquer more social status than the individual already possesses. The career may legitimize or reinforce this already existing status, however. For an individual from a lower social stratus, however, a career as a journalist may be an important tool for achieving social ascension. What must be understood here is that this chance of social change, even though it might be slight in quantitative terms, is a motivating factor that influences people in their choice of a profession, though this may not appear openly in the discourses of the journalists whom I interviewed.

Reflecting upon the journalist's role, I emphasize that he/she has an important function in terms of constructing citizenship, given that he/ she is responsible for transmitting information and the fact that citizenship is subordinated to information. Citizens cannot exist if they are uninformed and information transforms individuals into citizens to the degree that it makes possible evaluations, choices and participation in society. Without information, citizenship is restricted or even non-existent.

N. Canclini (1999, p. 89) relates the concept of citizenship with that of the consumer. In this point of view, the fundamental requisites of the process are: "the vast and diversified offerings of goods and messages that represent the international variety of the markets: multidirectional and trustworthy information with regards to the quality of products and the democratic participation of the principal sectors of civil society in decisions regarding the material, symbolic, juridical and political organizations within which consumption is conducted". For Canclini, it is through political actions such as these that consumers can ascend to the status of citizens, which demands a concept of the market not only as a place where merchandise is exchanged, but as an integral part of more complex socio-cultural interactions. The journalist thus plays a dual role. $\mathrm{He} / \mathrm{she}$ helps create citizenship through his/her professional duties as a producer of information and also as a consumer of the cultural industry itself. Many of the journalists whom I have interviewed affirm that one of the factors that led them to this professional career choice was its power 
to denounce, criticize and transform society.

While researching literary supplements in newspapers in Brazil and France (TRAVANCAS, 2001), I supported the idea that the journalist can be understood as an intellectual, a complex category that takes in a vast number of occupations. In order to better comprehend the meaning of the intellectual and his space of symbolic and political action, we must first explore this category in terms of the global transformations that have occurred in the societies in question, in the intellectual fields themselves and in the competition intellectualism has with other forms of political action. In other words, it is important that we take into consideration the contexts and intellectual traditions of each country that we study. Intellectuals have a different dimension in liberal societies than they do in undemocratic countries. For France, as for the great majority of European societies, the category "intellectual" - taken as an autonomous entity charged with symbolic and political capital and as an activity set in opposition to manual activity - dates from the days of the "Dreyfuss Affair". For historian C. Charle (1990), this category was born with the polemical judgment of Captain Dreyfuss in 1890. The apex of the Affair was the publication of Emile Zola's "J'accuse" in the newspaper L 'Aurore. Zola's text defended Captain Dreyfuss and attacked his condemnation. The concept of the "intellectual" designated a culturally and politically progressive stratus that defied the State. After the conclusion of the Affair, the term did not disappear and instead was used to identify a group that defined itself via a particular view of the social world, based on universal values.

In liberal societies, intellectuals have a different weight than in dominated societies. Likewise, in societies where illiteracy has not yet been abolished, the situation of the intellectual is also different from that of more "advanced" nations.

According to Gramsci (1978, p. 7)

All men are intellectuals. One can thus say: but not all men play the role of intellectuals in society. However, there is no human activity from which one can exclude all intellectual intervention. One cannot separate homo faber from homo sapiens.

It was not by accident that Gramsci referred to the literary critic, the philosopher and the artist as traditionally vulgarized types of intellectual. In his view, journalists judged themselves to be "true" intellectuals as they were included in all three of these occupations. Another salient point in Gramsci's perspective is the fact that he affirms that, in reality, there is no criterion by which one can distinguish nonintellectuals from intellectuals. This distinction does not come from an 
individual's activities, but from "the system of relationships in which these activities are found within the general set of social relationships" (1978, p. 7). This raises the question of group identity: it is not the fact that reporters write for newspapers or work in television that unifies them as a group, but a particular worldview and a specific ethos.

\section{A day in the life of a reporter}

The first research project included in the present article was undertaken in the 1990s and concentrated on print journalists in Rio de Janeiro. Over the course of two years, I interviewed some 50 journalists in order to better understand their professional practices and their relationship with their career. I did an ethnographical study of the newsroom and also accompanied three reporters employed by different newspapers on their daily rounds. One of these reporters worked for $\boldsymbol{O}$ Globo newspaper. I was with her from the moment she arrived in the newsroom, following her around town as she confirmed stories and returning with her to the newspaper where she would write up her material until it was time to go home. It is this experience which I describe in the second part of the article below.

Though my research into $\mathbf{O}$ Globo was undertaken over two decades ago, I believe that many of the elements that I uncovered at that time - both in terms of professional practices and the intensity with which journalists live their profession - continue to be a part of the reporter's working life. Also, even though both research projects are separated by several years and focused on different actors (mostly reporters in the first case and editors in the second), I believe that comparing these two news-worlds at distinct moments in time highlights permanent attributes of journalistic practices.

The second research project included in the present article took place in 2003 and 2004 and was restricted to the Jornal Nacional TV news crew and production crew. During the day, I followed the process through which the nightly news was put together, sitting in on meetings of several in-house and outside teams as they selected material for the broadcast and edited it up until the final moments before it went on the air. This experience will be discussed in the third part of this article.

I turn now to my experiences with the newspaper with a quote by journalist Ricardo Kotscho (1986, p. 22) "Reporters should only be reporters if there is nothing else open to them, if this is the only way to earn a salary, as if some force majeur pushed them to do it".

When I arrive in the newsroom, it is empty and silent. The 
reporter who has agreed to let me accompany her comes running in, and hurriedly greets me before bustling off to talk to the assignment editor. The editor is organizing the day's stories and the reporter gives him some advice. Nothing is confirmed yet for her and the chief reporter has not arrived yet. The reporter glances over the day's newspapers and comments about her story of the day before, asking about further research on it. My informant is assigned as a reporter to the Ceneral Stories staff. She is 25 years old and has been working for four years, three at this same newspaper. She is single and does not have any children. She lives in Niterói with her parents.

40 minutes pass by and the other reporters show up. My reporter logs on to her computer terminal to check her mail and look up possible stories. One can see from this activity that the computer is a key element that is incorporated into the reporter's life and she does not appear to have any difficulties in operating $i^{2}$. Many reporters, especially those who belong to the younger generation, have told me that they consider the computer to be the "greatest wonder in the world". Most reporters quickly adapted themselves to its use and have mastered it to browse through archives, send messages, suggest changes in texts, etc.

My reporter's computer indicates that a story about the Traffic Department is coming up, but only at 11:00 a.m. While she waits, she asks the Research Department for material about the subject in order to prepare for it.

Time passes slowly on this day. It is 10:00 a.m. and no new facts have come up. The reporter complains that she wants to hit the streets and that she is bored with waiting. She claims that she has never stayed all day in the newsroom before. The research material arrives and the reporter reads it and jots down some notes. A colleague asks for information about a topic that the reporter wrote about a few days earlier. The reporter takes advantage of the slow day to talk to me about the social relationships of her newsroom colleagues both at work and away from work. According to her, these relationships vary from one editorial staff to another. In general, it is easier to talk to each other on weekends when there are fewer people in the newsroom and the climate is more casual. There is always a lot of competition, though, and this is especially true when a new person joins the staff. She claims her day-today relationships with her colleagues at other newspapers are good and she passes information back and forth with them. In her opinion, this sort of behavior is basic to the business of being a reporter.

This image of solidarity between reporters at competing newspapers might surprise some readers. In the popular imagination, 
reporters are always looking for "scoops" and are often unscrupulous and selfish as they seek for a way to stand out from the crowd in their profession. We can see, however, that things are not exactly like this. Each reporter wants to get his/her story on the first page but, at the same time, there is an established agreement regarding how information is divulged among members of the profession. A scoop is not passed along to a colleague, but this does not happen every day. This attitude is part of a professional code which is understood and shared by many reporters.

According to my informant, journalism is a profession that has a glamorous image: reporters are supposedly generally well dressed and show up at the right places at the right times. "This image is linked to TV in my view," she says. "It is not what really happens". However, she emphasizes that she is in no way disappointed with her job; she is frustrated with her newspaper, not with her profession. The newspaper she works at makes her feel lethargic.

It is now 11:00 a.m. - time to hit the streets to verify the facts. The reporter tells her boss that she is going out and also tells him that I will be accompanying her. She calls for the photographer and, together, we all head down to the ground floor. There, the reporter talks to her driver and we get into his car. The atmosphere is calm and the reporter talks to the driver about where we are going. I have noticed, on other occasions, that the reporters' relationships with other members of the news team, such as drivers and photographers, are not always calm. On the contrary, generally these relationships are full of conflicts created, according to some of my informants, by the stress of the job itself. Sometimes photographers complain that reporters want to gather too much information or that they rush the photographer whom they feel is working too slow. On other occasions, drivers are criticized for not knowing the route to the sites the team needs to visit. As one journalist puts it, "we need to work at not fighting with each other because we depend upon each other".

The photographer rides in the front of the car next to the driver. My reporter-informant claims that this is the norm in journalism: if something happens en route, the photographer needs to be the first one out of the car in order to shoot it. She talks to the photographer about the story's possibilities, which she does not think are very good. "It probably won't amount to much," in her opinion. As soon as we arrive at our destination, she is to interview the director of DETRAN, the city's Traffic Department. Before this, however, the team decides to drive along the route where DETRAN has made the changes that will be discussed in the story.

In the DETRAN foyer, the reporter meets several colleagues from 
other newspapers. They greet her and tell her that the director is late and that the story in question is not very big. The journalists consider it to be a "cold" story, without much interest for the readers. Important stories are reports involving major unexpected happenings: these have a chance of getting on the front page or, at the very least, onto the right side of the newspaper ${ }^{3}$. The reporters are advised that the interview will begin in the director's office. During the interview, many reporters ask questions and almost everyone takes notes. Sometimes the TV and radio reporters (only one TV station is present) do not seem to be actually accompanying the event, as if their recorders or cameras were doing their work for them. The interview wraps up and the TV crew beats a rapid retreat, followed by the radio teams. Some of the print reporters stay, however, in order to obtain more details from the director. On our way out of the office, the reporters talk about the topic and exchange opinions about how to best situate the story and begin the write-up. Some of the reporters leave while others stay. We accompany the director to see, first hand, the streets where the traffic patterns will change.

On the way, the reporter and the photographer talk about the story and wonder if the changes will improve traffic in the city. Arriving at the site, they wait for the director to show up. The reporter talks on her own with the director when he arrives and the other reporters arrive shortly afterwards. They ask my reporter for information, which she passes along without any problem or hesitancy. While this is going on, the photographer does his job. As soon as the photo shoot is over, we get in the car and drive back to the newspaper. Both the reporter and the photographer start complaining about being hungry and start ironically commenting on the "pleasures" of the profession, which include not having a fixed lunch hour or place to eat. It is now 2:00 p.m.

Back in the newsroom, the reporter talks to the Reporting Editor and informs him about the story. After she receives some guidance on how to treat the story, she tells him she is going out for lunch. She looks around for colleagues who have not eaten yet. Most of the newsroom staff has already had lunch but one colleague is finishing a story and asks her to wait for him.

At lunch, the journalists talk about their relationships with their colleagues and the competition among them. Many believe that this competition exists and is accentuated by the fact that journalism offers no career plan, not even in terms of promotion for time served. Aside from questions of competency, one needs to be part of a group or be "chosen" by some boss and "pulled up". The reporters emphasize that in most cases, professional growth is associated with personal relationships 
involving friendship and sympathy. In order to be one of the "favorites", one needs to "break through" and attract or conquer a boss's attention.

After lunch, the reporters return to the newsroom to write their stories. For many, it is the "moment of anguish": trying to organize one's notes, thinking about what is more important, selecting the principal information to be presented and writing a good lead which is both informative and creative. It is a moment of worry and anguish. The reporter checks her information and reads the research material once again. She begins to write, erases her work, then writes again, and changes some things. The story begins to take shape on the computer screen. She calls out to a colleague and asks about the name of the street they visited because she did not write it down. The photographer sends up the proof sheet with the photos. The reporter chooses one and inserts the photographer's name into the story. At about 4:00PM she finishes. She rereads the material on the screen and "sends" it into the system where it is stored. The editor will pull it out from storage and revise it, making any changes he finds necessary. The reporter is now done for the day. She says goodbye to her colleagues and ends her workday by reading the newspaper and watching the TV news for up-to-the-minute reports.

\section{A day in the Jornal Nacional (JN) newsroom}

I arrived at the TV Globo studios at 10:00 a.m. The editor-inchief, William Bonner, explained that the first meeting of the day is the "box" meeting, so-called because it is carried out via speaker phone with the editors from the affiliates in other major Brazilian cities such as São Paulo, Brasília and Belo Horizonte and with journalists from London and New York. There are not many people in the room that early and he introduces me to the journalists who have arrived. I am identified as the "professor" who will accompany the news show's production that day. Bonner says that it is going to be a heavy day as there is a lot going on and some care will have to be exercised over what gets selected for broadcasting. The editors then come in: the arts editor, sports editor and one of the crew's journalists. The meeting then begins.

One of the structuring elements of TV news is the definition of how long it will run, which is flexible. $\mathbf{J N}$ runs from between 30 to 35 minutes with 4 station breaks at fixed intervals. The time allotted is established by the program's directors and will be discussed and renegotiated throughout the day by the editor-in-chief as a function of the reports which will be presented. It is the editor-in-chief's goal to get the maximum number of minutes possible. 
The meeting is quite casual with plenty of quips, complaints and jokes during the hour it lasts. Everyone receives a list of the reports which are scheduled for that day. One of the main themes of the meeting is Haiti. Bonner says that the capital probably will fall today and it certainly should be discussed in the news. The leader of the Aum Shinrikyo Sect was also condemned to death today in Japan, having been judged responsible for the sarin gas attack on the Tokyo subway in 1995. Bonner says he will ask the New York office to deal with that story. He accepts the offer of the representative of the London office for a report about the winter weather causing chaos in several European countries. Another important theme at the meeting is the coverage of the government of Brazilian president Luis Ignácio "Lula" da Silva. The editor-in-chief says that he evaluated yesterday's program and thinks that the show had been too "harsh" regarding the government. Today they will do a more "positive" story about the family welfare program. The vice-president is in the hospital and Lula has scheduled a visit. The editor immediately asks what happens if the vice-president dies. From the other side of the table, a journalist says that his condition is stable and apparently he is not in danger. One of the stories that will be presented today is a report about how all products containing transgenic ingredients must have this clearly listed on their packaging, beginning today. Bonner talks about the story. He says that JNS viewers do not know what "transgenic" means and that the news program will thus have to teach them about this controversial topic. Also on the schedule is another suggestion for a story regarding the numbers that the Lula government released for the Brazilian GDP. Bonner asks that the reporter talk to a "well-informed" economist. He explains to me that he wants someone clean-shaven who speaks well. I conclude that by this he means someone who has a serious demeanor and a certain level of knowledge. I remember Pierre Bourdieu's expression (1987, p. 41) regarding "obligatory speakers". These are the people who are frequently called to speak on television, giving their opinions and commenting on some happening. They are always available and are known as "media habitués". The meeting then turns to a discussion of a report regarding the fire department's obsolete and poorly maintained equipment. Bonner jokes that "journalists just love a fire" and refers to a fire that had recently occurred in a building in downtown Rio. He comments that there were no deaths and that this should only make the news on a slow day when they could ask for reports from other affiliates. One of the last things to be discussed is brought up by the sports editor: Guga, the tennis player, will be playing in Costa do Sauípe and the game will be transmitted by TV 
Record. Bonner says he will talk to the directors about how to proceed in this case and agrees that "the game cannot be ignored". They have to find out how long the game will last and if it will happen before or after JN goes on the air. In closing, Bonner says that he wants a light-hearted piece to end the day's news. Everyone then talks about other topics and TV programs until 11:30 a.m. when the meeting ends.

The production team will now call up those local affiliates which did not participate in the meeting, letting them know which stories will air on that night's program. Bonner calls me over to see a report about a celebration in an Indian village in Cuiabá. He says that he liked the report and jokes that it will go on the air in homage to me, the anthropologist. He also comments, however, that he does not like to see "Indians wearing clothes and flip-flops". To him, this means that they are losing their identity. I then comment about stereotypes and about the images which construct or reinforce them.

After lunch, we return to the newsroom. The story schedule meeting is about to take place in the same room where we had met earlier. 12 editors will take part in this meeting, including the economy, sports, art, international, GloboNews and city editor as well as editor and anchorwoman Fátima Bernardes.

This meeting has the same casual atmosphere as the earlier meeting, but is much louder. Before beginning, Bonner introduces me to everybody. There are plenty of jokes regarding the stories, often regarding the young Israeli woman who got shot on her Carnival holiday visit to Recife. The commentary has a very "black humor" aspect to it, especially regarding the fact that the tourist had left a violent country and had gone to Recife instead of Rio because the violence in the latter city scared her. Bonner then calls attention to the fact that yesterday they wanted to show that they were "independent of the government and we were merciless. Today we are going to tone it down. Yesterday we had a Folha SP moment" he says, making light of that São Paulo newspaper's reputation for double-barreled criticism. He returns to the topic of Guga the tennis player and says that they are going to ignore the event (his game with Maria Ester Bueno), but that if Guga gets hurt, "we'll cover it". Bonner then remarks about the Health Ministry, referring to a recent bone marrow transplant scandal, saying that it is good and faking a Pernambuco accent. In the middle of the conversation he suddenly swears. He looks at me and begs my pardon and then jokingly claims that I am already part of the crew as I have been there since early that morning. Several editors ask about various stories and comment on them. Bonner then 
talks about the coverage of the celebration in the Indian village and says "I don't like Indians". He immediately corrects himself and says "For the love of God, professor, I mean that I don't like stories about Indians". He then tells the editors that he "discovered" that I am an anthropologist... He then asks me if I liked the piece and whether or not I think it should go on $\mathbf{J N}$. I smile and say "too bad they're wearing clothes". After a few more jokes, questions and wisecracks, the meeting comes to a close. Some editors stay for the meeting about the schedule for tomorrow (Saturday). This meeting is much shorter and starts with comments about an error in yesterday's story on bone-marrow transplants. Bonner says that they will have to do another story and, during it, admit that "we were wrong. We look foolish correcting ourselves but we screwed up". Talk then turns to the stories about the city of Rio de Janeiro's upcoming birthday, the Grape Harvest Festival and a Portuguese celebration, among others. At the end of the meeting, Bonner comments that the day is stressful and the news show runs the risk of running out of time.

When we go back to the newsroom, it is much fuller, noisier and busier than before and the studio lights are already being tested. The deadline for finalizing the news program is coming up and the tension is building, as I have described elsewhere in my work on journalists (TRAVANCAS, 1993). The desk used to present the $\boldsymbol{J N}$ is in the same room, set up on a platform. The director of journalism, Ali Kamel, is in the newsroom and is in discussion with Bonner. Bonner then sits down and starts writing the script for the show. Now and then he is interrupted by a sub-editor who needs a question answered. An editor brings in a tape with a copy of the family welfare story and Bonner calls me over to watch it with him. He does not like it and says that it looks like a press release. The person being interviewed is looking at the camera, not the reporter. Bonner thus cuts the story from the program's schedule and asks that it be redone in order to go on the air on Saturday's program. Bonner then leaves the newsroom to prepare himself. He comes back quickly, ready to anchor the nightly news. Up to the last minute, the crew is discussing and evaluating what should and should not be presented on that night's program. The cameras come up and another edition of Jornal Nacional goes on the air.

The idea here has been to describe the routines of journalists involved in different media forms, highlighting their similarities and differences. The method I have used (ethnography) utilizes participantobservation and interviews as research tools in order to reveal how journalists think. I try to evaluate what has remained in journalistic 
practices over time and different media and, although this study is neither conclusive nor definite, it does describe a day in the life of two journalists, allowing valuable comparisons and contrasts to be made.

\section{Discussing the concept of news}

English researcher Stuart Hall (1980, in WOLF, 2004, p. 121) claims that culture is neither a practice nor simply a description of the habits and customs of a society. Instead, it appears through all social practices and their interrelations. In this sense, then, the mass communication media play an important role as an active element in collective development. Though the news and reporters are often considered to be secondary sources in the study of complex societies, I believe that they are the key to the production of everyday representations. As Sara Dickey points out in her article "La antropologia y sus contribuciones al estudio de los medios de comunicacion" (1997, p. 1), what is at issue here is the potency that journalistic representations have to construct identities, relationships and power. Without endorsing the perspective of the so-called "critical theory" or the "Frankfurt School" of which T. Adorno and M. Horkheimer (1985) are expressive representatives, I believe that the media contribute to the formation of subjectivities and to our own understandings of reality.

In the research presented above, I sought to accompany and describe how news is constructed in print and on TV. For me, news is a product of the complex interactions which constitute social life. From a wider universe of occurring facts, journalists select which facts will become news (and consequently divulged) according to a set of established criteria. Over time and across space, these definitions have been transformed but continue to be socially constructed. News is always anchored in criteria of classification, a taxonomy which is shared among journalists, readers, listeners and viewers.

A contract is established between news producers and viewers which can be labeled "the reading contract" (to use Eliseo Verón's term for it (1980)). This contract implies that the public agrees with or at least accepts the selective filter that journalists (re)construct on a daily basis and that produces a distinct way of reading social reality.

The news-consuming public does not notice what was left out of the news, nor does it understand how what was put into the news was chosen for broadcast. The public gives the journalist, in effect, a blank check to select what the public needs to know following the profession's hierarchies and criteria. This contract lies at the base of the concept of "newsworthiness" and the value set which guides news professionals. 
These values are the criteria utilized to select stories, from all the material available to the newsroom, for inclusion in the final news product. They guide journalists and news professionals, suggesting which facts should be emphasized and which should be omitted from the news. These values also help us to understand the velocity and superficiality with which journalists decide what is newsworthy and what is not. It is important to understand that this everyday logic of selection is based upon the news industry's routines of production and without it, no news producing agency could long survive as a profit-making concern.

Rules and criteria are necessary in order to deal productively with the large quantity of unforeseen events that occur daily in the world. Selection is a practical response to the uninterrupted flow and abundance of happenings. As Gans points out (1979, in WOLF 2004, p. 224), "The selection of news is a decision-making process of choice that is undertaken at a rapid pace (...) The criteria employed must be flexible and rapidly utilized so that one can make decisions without too much reflection". This is doubtless the reason why consensus exists among journalists regarding these choices and also why there is a clear hierarchy in the newsroom, where those who have more power impose their views.

It was quite evident to me that both media forms are in the business of deciding "what is news" over a short period of time and this situation has not changed as the decades have passed. It is this ability to rapidly apply criteria regarding what is or is not "news-worthy" and, secondarily, what should or should not go on the air or into the newspaper which constitutes the core of the journalistic worldview. This, in my view, is the element which draws both of the news worlds which I describe here together, in spite of their obvious differences in time, technology and media. In order for the news to be produced on time, a tacit consensus must exist beforehand among a given news-producer's journalists as to what constitutes news.

The Jornal Nacional is producing "infotainment" in the sense understood by Cristina Ponte (2004, p. 119): a journalism that considers as important the news which interprets happenings that have "human interest" to the degree that they are unusual or unheard of. This sort of journalism does not seek to inform, but seeks out facts that involve common people in unusual situations, the private life of celebrities or exceptional and/or heroic situations.

A comment made by Bonner at the end of the working day at the $\boldsymbol{J N}$ illustrates this state of affairs. He talked about some academic pieces written by researchers who, like me, spent the day observing 
the newsroom's routines: "They talked badly about the news and criticized it a lot. You'll do that too." I thought about how distant the academic and news worlds were from each other in terms of their exchange relationships. As Golding-Elliot points out (in WOLF, 2004, p. 218), describing this relationship, "what the sociologist describes as an inevitable consequence of productive organization, the journalist understands as an accusation of manipulation or incompetence ${ }^{4}$."

We can thus see how the value and criteria for producing news are naturalized by journalists in their daily professional labors. These aspects end up operating as hidden structures which push journalists towards a consensual understanding of the world. This is implicit in the belief that a journalist has a "sixth sense" or a "nose" for news, a notion which is also based upon the idea that news is something rare and of interest to human beings. This view, however, does not demonstrate the distinct cultural and ideological dimensions that permeate the news, nor the power relationships that these dimensions often cover up.

We thus know that journalism produces its discourses under a given set of specific conditions and that these are neither culturally nor socially neutral, even though journalists do not often admit this fact. For journalism, objectivity, clarity and concision are the basic rules of news. Though today's writing manuals claim that objectivity has lost some of its relative weight within this holy trinity, it has not been discarded and continues to be a major goal. This is the case with the Folha de $\boldsymbol{S}$. Paulo's Manual da Redação (Writing Manual, 2001, p. 28), which declares that "objectivity does not exist in journalism. In choosing a story, writing it up and editing it, the journalists makes a series of decisions which are largely subjective and which are influenced by his personal positions, habits and emotions. This does not, however, free the journalist from the obligation of being as objective as he possibly can. To report a fact faithfully, reproducing its forms, circumstances and repercussions, the journalist needs to look at it coldly and from a distance. This does not signify disinterest and apathy, however".

With the transformation of newspapers into companies whose main product is the news, there has been an attempt to homogenize the texts produced by the newsrooms. The concept of the "lead", for example, was created by the American print media and was practically universally adopted as a means of attending to a rapid reader's need to obtain the greatest amount of information in the shortest time possible.

The modern profession of journalism today demands that journalists be able to create and innovate based on the lead's formulaic 
approach to news, responding with efficiency to the main questions raised by the story. Many newspapers continue to follow this pattern, even today. Others have adopted different models, mixing formulas and creating spaces for greater individualization and subjectivity, such as authored columns. I discussed this theme (TRAVANCAS, 2001) in my article "A coluna de Ibrahim Sued: um gênero jornalístico" (Ibrahim Sued's column: a journalistic genre), in which I state that authored columns are a reserved territory where subjectivities, opinions and personalities can be freely expressed for the reader's pleasure and with the agreement of the newspaper.

In analyzing the coverage which the French newspapers Le Monde and Libération gave to the Brazilian elections in 1984 (TRAVANCAS, 1985), I could see that the descriptions French reporters made of the Brazilian political scene - and in particular of the "Direct Elections Now!" movement - were an expression of certain common French political concepts. It was thus not surprising to me that the title of one of Libération's editorial columns in support of the movement was "The starting point of democracy". In the French worldview, the "starting point of democracy", the point from which a society can begin to achieve democracy, was the free and direct election of the president. It was as if it were impossible for the press to think of a country - France, for example - without an attendant republic, liberty, democracy and fraternity.

The perspective of the French newspapers in this example is something similar to what T. Todorov describes as ethnocentrism (1993, p. 21-2). For Todorov, ethnocentrism "consists of unduly erecting universal values which are simply the specific values of the society that I inhabit". Ethnocentrism thus begins with the particular and seeks to generalize this, casting what is familiar and present in one's own culture as universal among humans. In this sense, "democracy" was understood by the French newspapers to be a universal value, present in all societies as an objective that needed to be achieved.

The specific way in which a newspaper sees, describes and classifies political happenings is an important starting point for understanding the newspaper itself. Many French reports, for example, associated the "Direct Elections Now!" movement with celebrations and music, highlighting these as essential Brazilian characteristics. Furthermore, these were often selected according to a view that the exotic is attractive to the French news-consuming public. This becomes clear in a selection from a large article published in Le Monde on April 25,1984 . In this text, the correspondent describes in detail the "party" 
(demonstration) he attended, which he feels began quite well, with masses of people singing, dancing and marching in the streets. He talks about the young women wearing bikinis covered with slogans such as "Direct Elections Now!" and lyrics from popular Brazilian songs. "In the country of macumba, those who do not want direct elections are exorcized as if they were possessed by the Devil. During the parades a cardboard dragon made an appearance: the monster of indirect elections."

The reading given to this campaign and the Brazilian political process then underway at that moment is that these were analogous to a party or a voodoo ritual. I do not wish to deny that there is a wellestablished connection between Carnival, elections and music during Brazilian political campaigns. However, the French sought to emphasize and highlight these connections and manifestations which were, in their eyes, charming and exotic.

In his article "Jornalismo: toda notícia que couber, a gente publica" (Journalism: all the news that is fit to print, we publish), historian R. Darnton (1990, p.70-97) briefly speaks about his experiences as a reporter for The New York Times and analyzes the social construction of the news, based upon the specific characteristics of working as a journalist and correspondent for the paper. Darnton emphasizes the fact that the NYT switches its correspondents around every three years. The paper believes that there is a tendency for its foreign correspondents to develop a favorable view of the country in which they work. An important concern is behind this strategy: the belief that the newspaper, understood as a construction of reality that "maps" the world for its readers, should be in harmony with the interests, objectives and perspectives of its reading public.

Journalists play an important role in the construction of news, not only as its producers, but also in their capacity as people who decode the world for news consumers utilizing the logic of newsworthiness, the editorial criteria of the news production organizations for which they work, and their views of the world.

\section{Final Comments}

This article is not an attempt to exhaust the question of how one does ethnography in the field of journalism. It is simply an attempt to discuss journalistic practices and to identify their particularities from an anthropological perspective.

I believe that today, more than ever, we need to reflect upon the role which the mass communication media play in so-called complex societies. The study of the media can be a valuable entry point for our 
comprehension of the social phenomena produced by the "natives" of these societies and can aid us in understanding their "codes" and "maps". In her review of the intersection between anthropology and communication, Debra Spitulnik (1993) calls attention to the fact that we still cannot speak of "an anthropology of the mass communication media", though there has been more interest in studying this topic in recent decades. According to Spitulnik, there are several ways of anthropologically approaching the communication media. They can be looked at as institutions, as workplaces, as communicative practices, as cultural products, as esthetic forms and as historical developments.

The mass communication media thus present a new challenge for anthropology. The enormous diversity of the products that these media are constantly producing and distributing demands from researchers a wider notion of the idea of ethnography itself.

In conclusion, I can say that although much has changed in the Brazilian press over the last 20 years, much has also remained the same. In general, journalism has suffered an immense impact from digitalization, both in terms of how the news is produced and distributed. Daily newsproducing routines, however, have not altered that drastically. Journalists also continue to have an intense relationship with their profession, a relationship that continues to generate a specific lifestyle and worldview. The journalist's relationship to society also continues to be influenced by his/her professional practices. As Bourdieu has pointed out (1997, p.25), "journalists have special lenses through which they see certain things and not others; and they see in a certain way those things which they do see".

\section{| NOTES}

1 A smaller version of this article was part of the Media Production Analysis Working Group at IAMCR 2010 in Braga, Portugal, in July 2010.

2 It should be noted that in the 1990s, when this study took place, computers were still relatively exotic technology in Brazil and few people knew how to use them competentlya.

3 The pages of the right side of the newspaper are more highly valued among reporters because they attract the reader's eye first.

4 Pernambuco is the state in the Brazilian northeast where the city of Recife is located. 
Author's translation.

6 A vulgar term for African-Brazilian religions. "Voodoo" would perhaps be appropriate in English

\section{| BIBLIOGRAPHY}

ADORNO, T. \& HORKHEIMER, M. Dialética do esclarecimento. Rio de Janeiro: Jorge Zahar, 1985.

BOURDIEU, P. Sobre a televisão. Rio de Janeiro: Zahar, 1997.

BUCCI, E. Sobre ética e imprensa. São Paulo: Cia das Letras, 2001.

CANCLINI, N. Consumidores e cidadãos. Rio de Janeiro: EdUFRJ, 1999.

CHARLE, C. Naissance des intellectuels. Paris: Minuit, 1990.

DARNTON, R. O beijo de Lamourette. São Paulo: Companhia das Letras, 1990.

DICKEY, S. La antropologia y sus contribuciones al estudio de los medios de comunicacion. In: Revista Internacional de Ciências Sociais, UNESCO 153: 1-23,1997. Available at <www.unesco.org/issj/rics153/ dickeyspa.html>. Accessed 15 dez. 2010.

FOLHA DE SÃO PAULO. Manual de Redação: Folha de S. Paulo. São Paulo: PubliFolha, 2001.

GRAMSCI, A. Os intelectuais e a organização da cultura. Rio de Janeiro: Civilização Brasileira, 1978.

KOTSCHO, R. A prática de reportagem. São Paulo: Ática, 1986.

PONTE, C. Leituras das notícias - contributos para uma análise do discurso jornalístico. Lisboa: Livros Horizonte, 2004.

SIMMEL, G. A metrópole e a vida mental. In: VELHO, O. (Org.). o fenômeno urbano. Rio de Janeiro: Jorge Zahar, 1979.

SPITULNIK, D. Anthropology and mass media. In: Annual Review of Anthropology, n. 22, p. 293-314, 1993.

TODOROV, T. Nós e os outros - a reflexão francesa sobre a diversidade humana - I. Rio de Janeiro: Jorge Zahar. 1993.

TRAVANCAS, I. O Brasil na imprensa francesa e brasileira. PUC-Rio: 1985. Monografia. Mimeo.

O mundo dos jornalistas. São Paulo: Summus, 1993.

O livro no jornal. São Paulo: Ateliê Editorial, 2001.

A coluna de Ibrahim Sued: um gênero jornalístico. In:

Revista Brasileira de Ciências da Comunicação. São Paulo: XXIV, n.1, p. 109- 122, jan./jun. 2001.

Juventude e televisão. Rio de Janeiro: FGV, 2007. 
VELHO, G. e KUSCHNIR, K. (Orgs.). Mediação, Cultura e Política. Rio de Janeiro: Aeroplano, 2001.

VERON, E. A produção de sentido. São Paulo: Cultrix, 1980.

WOLF, M. La investigación de la comunicación de masas. Buenos Aires: Paidós, 2004.

Isabel Travancas is an assistant professor at the School of Communication of the Federal University of Rio de Janeiro (UFRJ). She is a journalist with a Master in Social Anthropology from the National Museum (UFRJ) and a Doctorate in Comparative Literature from the State University of Rio de Janeiro (UERJ). She is the author of $O$ mundo dos jornalistas (The World of the Journalist, Summus Editorial: 1993), O livro no jornal (Books in Newspapers, Ateliê Editorial: 2001) and Juventude e televisão (Youth and Television, FGV: 2007). 